\title{
EFFECT OF THE REBURNING ZONE STOICHIOMETRY ON THE NOX CONCENTRATION AT THE THREE-STAGE COMBUSTION OF PULVERIZED COAL
}

\author{
Nelya Chernetskaya ${ }^{1, *}$, Mikhail Chernetskiy ${ }^{1,2}$, and Andrey Zhuikov ${ }^{1}$ \\ ${ }^{1}$ Siberian Federal University, 660074 Krasnoyarsk, Russia \\ ${ }^{2}$ Institute of Thermophysics SB RAS, 630090 Novosibirsk, Russia
}

\begin{abstract}
Numerical study of heat and mass transfer taking into account the combustion of coal particles in the furnace at the three-stage combustion of pulverized coal was performed. Analysis of the reburning zone stoichiometry on the concentration of nitrogen oxides at the furnace outlet was made. The values of excess air in the primary and reburning combustion zones, providing for the concentration of nitrogen oxides at the furnace outlet is not more than $350 \mathrm{mg} / \mathrm{m}^{3}$ and unburned carbon not more than $1 \%$ when burning coal with a high content of nitrogen were established.
\end{abstract}

\section{Introduction}

One of the main atmosphere polluters, greatly impacting on human health at the coal combustion in thermal power plants boilers are nitrogen oxides. Nitrogen oxides occurring during coal combustion for the mechanism of formation are divided into thermal, fast, and fuel. Thermal $\mathrm{NO}_{\mathrm{x}}$ results from the reaction of atmospheric nitrogen with oxygen at temperatures above $1500{ }^{\circ} \mathrm{C}$. Prompt $\mathrm{NO}_{\mathrm{x}}$ is generated in the presence of hydrocarbon radicals, it prevail in fuels with high value of the hydrogen to carbon $\mathrm{H}: \mathrm{C}$ ratio. Fuel $\mathrm{NO}_{\mathrm{x}}$ contributes to the total quantity of nitrogen oxides formed during flaring coal. Fuel nitrogen contained in coal, partly comes out with the volatile with the remaining part appearing during the combustion of coke residue.

Applying technological methods to the combustion process allows significantly reduce the nitrogen oxides concentration in exhaust gases of boilers. Works [1-7] are known for the two most effective technological methods of $\mathrm{NO}_{\mathrm{x}}$ reduction: applying low- $\mathrm{NO}_{\mathrm{x}}$ burners (LNBs) and, two and three-stage combustion.

Three-stage combustion (reburning) is the most complex process, but can give a significant reduction in the nitrogen oxides concentration. As shown by laboratory [8-11], as well as a number of industrial tests, this scheme of combustion permits reduction the nitrogen oxides emissions by up to $50 \%$. The use of these methods can lead to increased unburned carbon-in-fly ash at the furnace outlet. Therefore, the reduction of unburned

*Corresponding author: micch@yandex.ru 
carbon-in-fly ash at the furnace outlet, in addition to reducing $\mathrm{NO}_{\mathrm{x}}$ concentrations, is one of the criteria of these methods.

Computational fluid dynamics methods are essential part of the work during implementation of reburning. Models describing the rate of coal burnout and the nitrogen oxides formation play a significant role in the accuracy of the results. The complexity of these processes explained, in particular due to their close relationship with the physical and chemical phenomena, taking place in the furnace [13]. Therefore, in spite of a number of works in this direction $[4,6,12]$, the choice of the mathematical model, which would ensure correct results, remains relevant.

This paper presents the influence of reburning zone stoichiometric ratio on the $\mathrm{NO}_{\mathrm{x}}$ concentration and unburned carbon-in-fly ash by mathematical modeling.

\section{Problem statement and research methods}

As research object selected combustion chamber unit at supercritical steam parameters with capacity of $660 \mathrm{MW}$ with a steam capacity of $1830 \mathrm{t} / \mathrm{h}$ at a pressure of $28 \mathrm{MPa}$ and temperature of $600{ }^{\circ} \mathrm{C}[14]$. This boiler is a pilot project of Russian developers. Project fuel for this boiler is Kuznetskiy coal, the composition and characteristics of whose are presented in table 1 .

Table 1. Composition and characteristics of coal.

\begin{tabular}{|l|l|l|l|l|l|l|l|l|l|}
\hline \multicolumn{7}{|c|}{ Consist, \% } & $\begin{array}{l}\mathrm{Q}_{\mathrm{i},}^{\mathrm{r}} \\
\mathrm{kcal} / \mathrm{kg}\end{array}$ & $\mathrm{V}^{\text {daf }} \%$ & $\mathrm{R}_{90} \%$ \\
\hline $\mathrm{W}^{\mathrm{r}}$ & $\mathrm{A}^{\mathrm{r}}$ & $\mathrm{C}^{\mathrm{r}}$ & $\mathrm{S}^{\mathrm{r}}$ & $\mathrm{H}^{\mathrm{r}}$ & $\mathrm{N}^{\mathrm{r}}$ & $\mathrm{O}^{\mathrm{r}}$ & & & \\
\hline 11.0 & 18.92 & 53.92 & 0.43 & 3.84 & 1.71 & 10.18 & 5000 & 41.0 & 18 \\
\hline
\end{tabular}

The furnace with solid slag removal for the boiler has a prismatic shape $(18.7 \times 18.7 \mathrm{~m})$ with corner tangential placement of the burners. Given the stringent requirements for $\mathrm{NO}_{\mathrm{x}}$ emission and taking into account the high nitrogen content in the fuel, to achieve the minimum $\mathrm{NO}_{\mathrm{x}}$ concentrations provides a furnace scheme with the implementation of reburning (fig. 1a). Burners are placed in three tiers. Each burner has two nozzles of coalair mixture. The reburn burners are tangential location. OFA nozzles are arranged
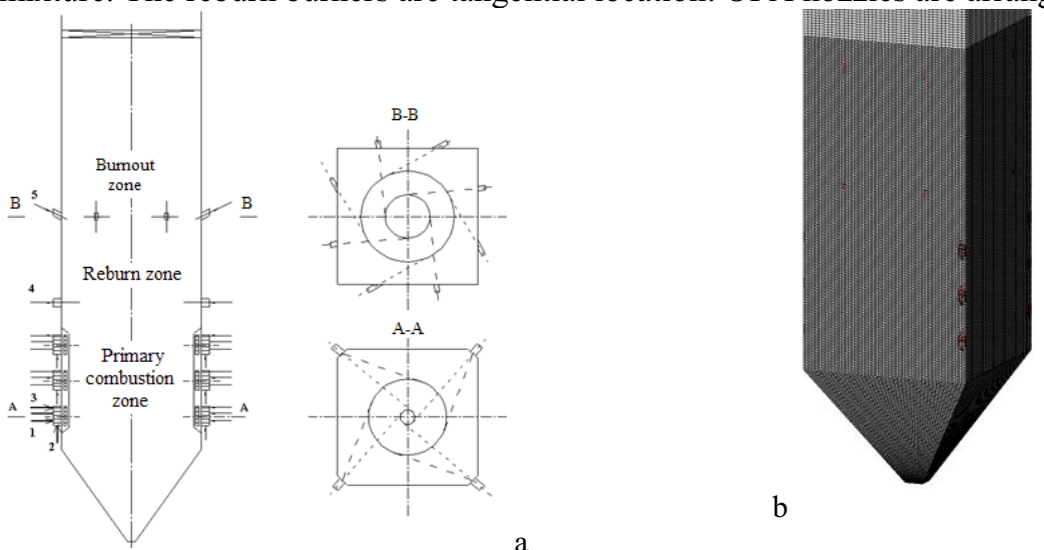

b

a

Fig. 1. The geometry of the combustion chamber. a) furnace scheme. 1 - coal-air mixture, $2-$ secondary air, 3 - gas recirculation, 4 - reburn fuel, 5 - OFA б) computational mesh of the furnace. 
tangentially on the furnace walls with the direction of twist opposite to the main torch. In the draft of the boiler, to the combustion chamber imposes restrictions on concentration of nitrogen oxides - not more than $350 \mathrm{mg} / \mathrm{m}^{3}$.

The experimental studies $[2,7,8]$ showed that one of the main parameters having a significant influence on the nitrogen oxides concentration at the outlet of the furnace with reburning technology is the reburning zone stoichiometry. When reducing the stoichiometric ratio in the reburning zone on $\mathrm{NO}_{\mathrm{x}}$ concentration at the outlet of the furnace is reduced, the amount of unburned carbon in the fly ash is increasing.

The main aim of this research is the numerical investigations of stoichiometric ratio influence at the furnace outlet the regenerative combustion zone on the concentration of $\mathrm{NO}_{\mathrm{x}}$ and unburned carbon- in-fly ash.

The computational were performed using the in-house finite-volume block-structured CFD package SigmaFlow. This CFD-package has been successfully used for solving the optimization process in the furnace $[15,16]$. The complete combustion model considers the process as a flow of incompressible nonisothermal multicomponent reacting gas-particle mixture, using Euler- Lagrangean frames for the gas-phase and particles respectively. The field variables are described by Reynolds averaged equations for conservation of mass, momentum, enthalpy and mixture fraction of species concentration. The gaseous phase is treated as a single-phase fluid in which the effects of the dispersed reacting coal particles on the gaseous phase were accounted for by the PSI-Cell method. The RANS equations are closed with the standard high-Re-number k- $\varepsilon$ turbulence model. More details about the model and numerics of SigmaFlow can be found in Chernetskiy et al. [17]. Calculation of volatile fuel components combustion is based on the use of global irreversible reactions between fuel and oxidant. To describe the reaction in turbulent flows with large mixing time used a hybrid model using the kinetic model and the eddy break up model to determine the reaction rate. The modeling of radiant energy transfer is conducted basing on the P1 approximation of spherical harmonics for a grey medium. The advantage of this method is easiness of its matching with methods of aerodynamics and heat transfer calculation realized in curvilinear meshes. The absorption coefficients were calculated using the weighted-sum-of-gray-gases model. The Lagrange method was used in the present work to describe of particle motion. Coal particle devolatilization as well as char combustion are approximated by one- component schemes using a kinetic-diffusion model. In the modelling of $\mathrm{NO}_{\mathrm{x}}$ formation two mechanisms are taken into account: formation of thermal $\mathrm{NO}_{\mathrm{x}}$ (according Zeldovich's model [18]), formation of prompt $\mathrm{NO}_{\mathrm{x}}$ and formation of fuel $\mathrm{NO}_{\mathrm{x}}$, (Chen [19] and DeSoute [20]).

Conservation equations for gas phase are written down in a generalized conservation law in a control volume. For the volume finite-difference analog of equation is written down. For calculation of diffusion flow on the face of control volume centrally-difference scheme with second order precision is employed. At the approximation of convective terms Leonard's scheme is employed that is substantially minimizes the circuit viscosity. For connection velocity and pressure fields SIMPLE-C procedure is employed.

\section{Results and discussion}

Geometry and computational mesh of the combustion chamber are shown in figure 1. To perform the computational studies it is accepted that the main burner is supplied $80 \%$ of the fuel, on the reburn zone of $20 \%$. Distribution of coal, air and gases recirculation main burners is uniform. The excess air coefficient at the exit from the active combustion zone (main burner) $\sim 1.1$, excess air coefficient in the recovery zone was varied in the range 0.9 -1.05 , and at the furnace outlet is 1.2 . 
According to the results of computational studies established that the tangential burner ensures the formation of a central vortex in the center of the furnace and secondary vortices along the walls. The gases flow through nozzles with the reverse twist flow, relative to the main burners, ensures good mixing of combustion products with coal-air flows.

Figure 2 shows temperature fields in the central section of the furnace at different excess air ratio in the reburn zone. For all variants, in the primary combustion zone, the temperature near the walls does not exceed $1000{ }^{\circ} \mathrm{C}$, which is admissible for the Kuznetsky coal from the point of view of heating surfaces slagging. While decreasing the excess air ratio at the exit of the reburn zone, increases the amount of air supplied to the OFA nozzles for afterburning products of incomplete combustion. This leads to differences in the temperature field in the OFA zone. But in general, for all variants, there is a homogeneous temperature distribution in horizontal cross section and incident radiative fluxes along the perimeter of the combustion chamber, ensuring excellent mixing of the overfire air and the upward coal-gas-air flow and a good fuel burnout. The maximum combustion temperature reaches $1650{ }^{\circ} \mathrm{C}$. At the outlet from the furnace chamber temperature are in the range 1140 $1150^{\circ} \mathrm{C}$, which avoids slagging of screens.

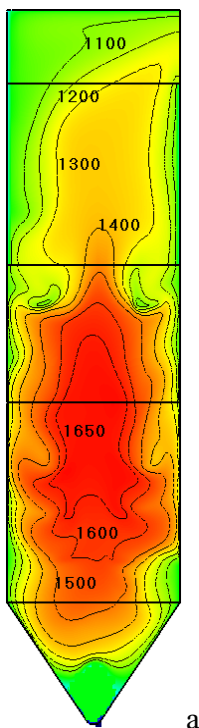

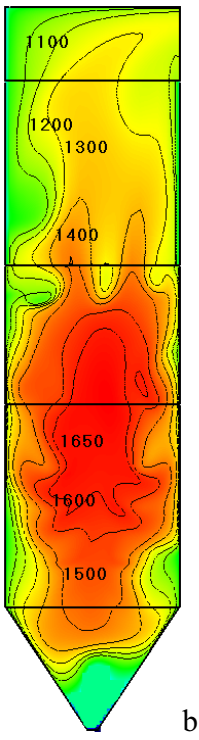

b

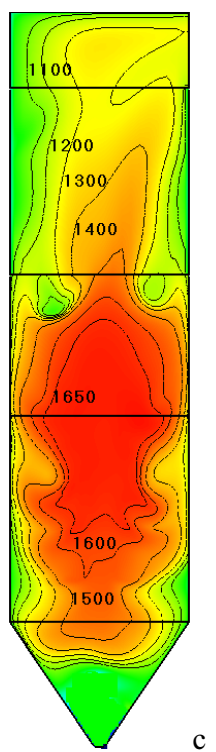

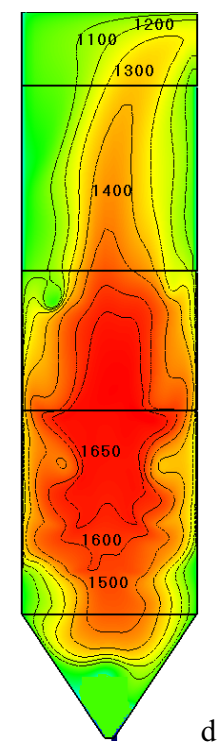

Fig. 2. Temperature field in the central section of the furnace at different reburning zone stoichiometry, ${ }^{\circ} \mathrm{C}$. a) $\alpha=0.9$; b) $\alpha=0.98$; c) $\alpha=1$; d) $\alpha=1.05$.

Figure 3 shows the nitrogen oxides concentration in the central section of the furnace. From the drawings it is seen that all cases in the active combustion zone demonstrate the same distribution and nitrogen oxides concentrations. At the exit from the primary combustion zone the $\mathrm{NO}_{\mathrm{x}}$ reading is $\sim 550 \mathrm{mg} / \mathrm{m}^{3}$ for all options due to same value of excess air at the exit from the primary combustion zone.

In the reburn zone while decreasing the air excess ratio there is a more effective interaction of incomplete combustion products with $\mathrm{NO}_{\mathrm{x}}$ (fig. 3) formed in the main burner zone, and there is a recovery of them to the molecular nitrogen. To the greatest extent, the reduction of $\mathrm{NO}_{\mathrm{x}}$ occurs when $\alpha=0.9$, where at the level of the OFA nozzles the nitrogen oxides concentration reaches values of $130 \mathrm{mg} / \mathrm{m}^{3}$. For the case of $\alpha=1.05$ there is a significant $\mathrm{NO}_{\mathrm{x}}$ concentration in the central zone (fig.3d) and the mean value $\mathrm{NO}_{\mathrm{x}}$ concentration at the level of the OFA nozzles is more than $650 \mathrm{mg} / \mathrm{m}^{3}$. At the exit of the combustion chamber for all considered variants is observed a uniform distribution of the 
nitrogen oxides concentration. The $\mathrm{NO}_{\mathrm{x}}$ values for option with $\alpha=0.9$ is $160 \mathrm{mg} / \mathrm{m}^{3}$, whereas for the case of $\alpha=1.05-650 \mathrm{mg} / \mathrm{m}^{3}$.
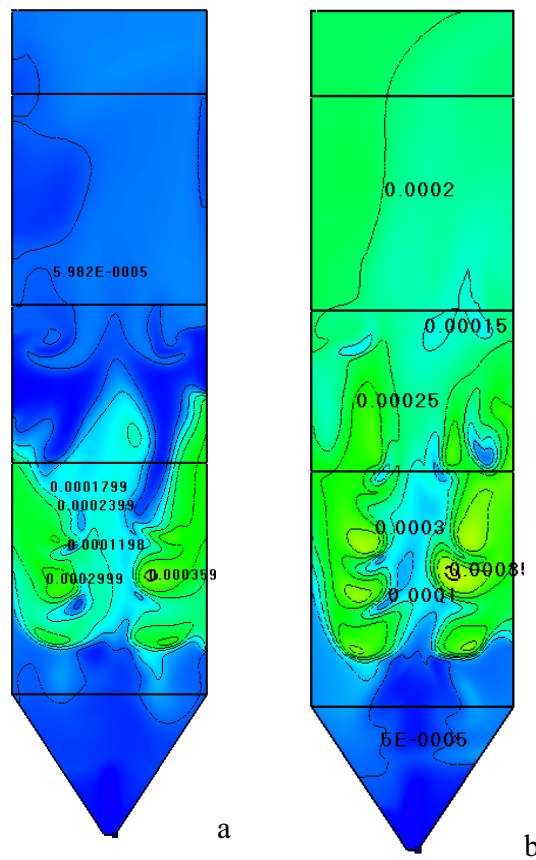

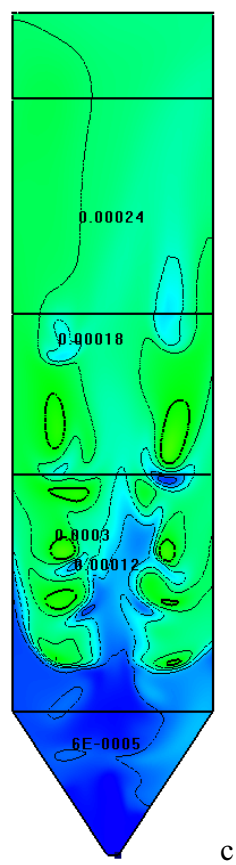

Fig. 3. Nitrogen oxides concentration in the central section of the furnace at different reburning zone stoichiometry, $\mathrm{kg} / \mathrm{kg}$. a) $\alpha=0.9$; b) $\alpha=0.98$; c) $\alpha=1$; d) $\alpha=1.05$.

Despite the existence of the reburning zone and the same coefficient of excess air at the outlet of the furnace there is a difference in unburned carbon-in-fly ash. Reducing the amount of air in reburning zone increases the number of incomplete combustion products at the reburning zone outlet. So, for the case of $\alpha=1.05$, unburned carbon-in-fly ash q4 is $0.4 \%$, whereas for the case of $\alpha=0.9-\mathrm{q} 4 \sim 2 \%$. Figure 4 shows the dependence of the $\mathrm{NO}_{\mathrm{x}}$ concentration and unburned carbon-in-fly ash at the furnace outlet from the excess air ratio at the reburninig zone.

From figure 5 we can see the decrease the nitrogen oxides concentration and increase the unburned carbon-in-fly ash at the furnace outlet when reducing the stoichiometric ratio in the reburn zone. 


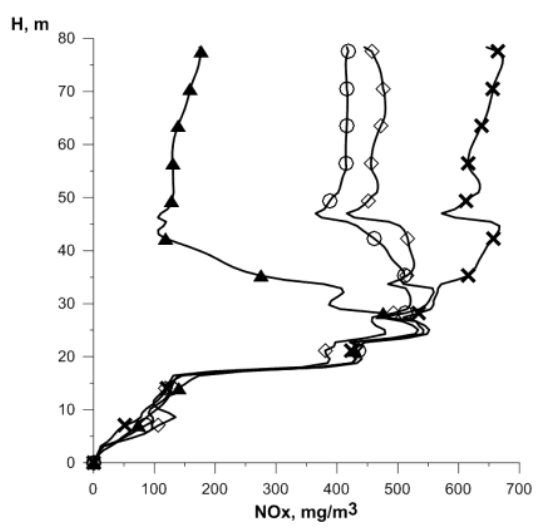

Fig. 4. $\mathrm{NO}_{\mathrm{x}}$ concentration at the furnace height. $\Delta-\alpha=0.9 ; \circ-\alpha=0.98 ; \diamond-\alpha$ $=1.0 ; \times-\alpha=1.05$.

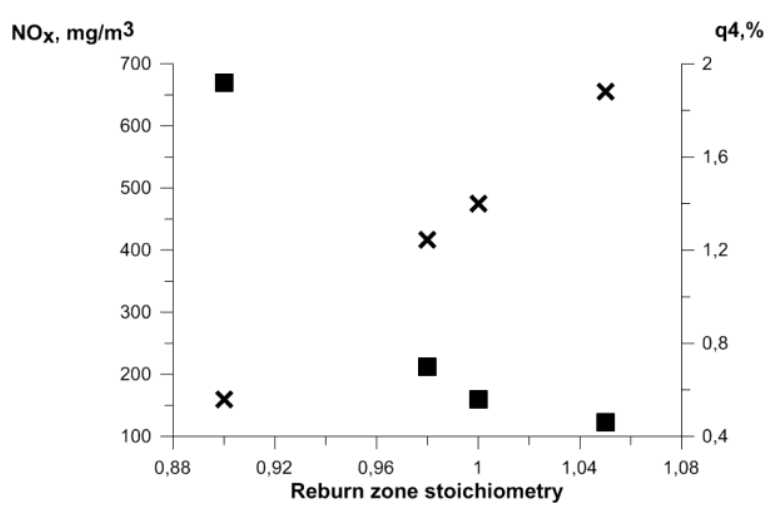

Fig. 5. The dependence of the $\mathrm{NO}_{\mathrm{x}}$ concentration and unburned carbon at the outlet of the furnace from reburning zone stoichiometry. $-\mathrm{q} 4, \times-\mathrm{NO}_{\mathrm{x}}$.

Given the imposed project constraints to the furnace, the nitrogen oxides concentration is not more than $350 \mathrm{mg} / \mathrm{m}^{3}$ and the value of unburned carbon-in-fly ash no more than $1 \%$, the value of $\alpha$ must be in the range of $0.94-0.98$.

\section{Conclusion}

The performed numerical studies reveal a significant influence of stoichiometry in the reburning zone in the formation the nitrogen oxides concentration. It is shown that the change stoichiometric ratio in the range of $0.9-1.05$ leads to changes in the $\mathrm{NO}_{\mathrm{x}}$ at the furnace outlet on more than 4 times.

The dependencies of the $\mathrm{NO}_{\mathrm{x}}$ concentration and unburned carbon-in-fly ash at the outlet of the furnace unit capacity of 660 MW while burning Kuznetsky coal from the stoichiometric ratio in the reburn zone have been defined. It is shown that to ensure the nitrogen oxides concentration at the furnace outlet at less than $350 \mathrm{mg} / \mathrm{m}^{3}$ and unburned carbon at less than $1 \%$, the value of $\alpha$ must be in the range of $0.94-0.98$.

\section{Acknowledgments}

The research on modelling combustion coal and associated heat and mass transfer phenomena was supported by RFBR, research project No. 15-38-20969.

\section{References}

1. J.C. Kramlich, W.P. Linak, Prog. Energy Combust. Sci. 20 (1994)

2. V.I. Babii, V.R. Kotler, S.P. Titov, T.M. Balashova, Topical issues of burning energy fuel (1980)

3. V.R. Kotler, Reduction in nitrogen oxides emissions boilers of thermal power plants during solid fuel combustion (Souzenergo, 1982)

4. H. Zhou, K.F. Cen, J.R. Fan, Energy 29, 1 (2004)

5. C.T. Bowman, 24th Symposium (International) on Combustion, The Combustion Institute, Pittsburgh (1993)

6. S.C. Hill, L.D. Smoot, Prog. Energy and Combust. Sci. 26, 4 (2000) 
7. B. Staiger, S. Unterberger, R. Berger, K.R.G. Hein, Energy 30, 8 (2005)

8. L.D. Smoot, S.C. Hill, H. Xu, Prog. Energy and Combust. Science 24, 5 (1998)

9. B. Folsom, Fuel Energy Abstr. 4, 227 (1997)

10. B.X. Shen, Q. Yao, X.C. Xu, Fuel Processing Technology 85, 11 (2004)

11. H.P.Wan, C.S. Yang, B.R. Adams, S.L. Chen, Fuel 87, 3 (2008)

12. W.P. Adamczyk, S. Werle, A. Ryfa, Applied Thermal Engineering 73 (2014)

13. Y.A. Anikin, I.S. Anufriev, E.Y. Shadrin, O.V. Sharypov, Thermophysics and Aeromechanics 21, 6 (2014)

14. A.G. Tumanovskii, M.Yu. Altukhov, A.L. Shvarts, and other, Power Technology and Engineering 44 (2010)

15. M.Yu. Chernetskii, A.N. Alekhnovich, A.A. Dekterev, Thermal Engineering 59, 8 (2012)

16. Maidanik, M.N., and other, Thermal Engineering 58, 6 (2011)

17. M.Yu. Chernetskiy., A.A. Dekterev., A.P. Burdukov, K. Hanjalić, Fuel 135 (2014)

18. Y.B. Zeldovich, P.Y. Sadovnikov, D.A. Frank-Kamenetckiy, AS USSR 317 (1947)

19. W. Chen, $\mathrm{PhD}$ thesis of Brigham Young University (1994)

20. G.G. DeSoete, In: Fifteenth symposium (international) on combustion. The Combustion Institute (1975) 